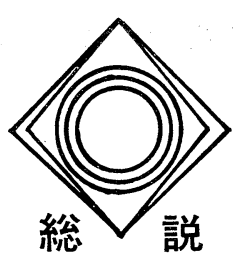

1.はしがき

煙道などより放出される污染物は拡散稀釈される が，しかしそれによって大気中より消兑てしまったわ けではない。例㓪ば二酸化炭素 $\left(\mathrm{CO}_{2}\right)$ やフレオンが 大気中で蓄積されつつあることを考光ても明らかであ る。

污染物が大気中より除去され，水圈または土䁃中に 戻るには次の機構が働らいている。(1)土袞面，水面㐫 るいは地表にある植物や構造物への沈着, (2)雲や霧に 捕捉せられ，次いで雨や雪に捕捉せられて地上へ落 下 (rainout), (3)雨や雪が落下の途中直接污染物を捕 集 (washout)。さらに間接的ではあるが，化学反応 などの変換によって污染物を除去し易い形（あるいは その逆の場合もある）に変化させる。

最近スウェーデンやノルウェーの人々によって指摘 されたように, 二酸化硫黄 $\left(\mathrm{SO}_{2}\right)$ やその他の污染物 が中欧諸国より数百 $\mathrm{km}$ 以上にわたって長距離輸送 され，その途中で強酸性物質に変換されて酸性雨を惹 起した。アメリカでは $\mathrm{SO}_{2}$ や硫化水素 $\left(\mathrm{H}_{2} \mathrm{~S}\right)$ より 変換した硫酸塩粒子 $\left(\mathrm{SO}_{4}{ }^{2-}\right)$ が広域に分布し人体な ぞに与える影響が䯚念されている。またアメリカやわ が国などでもみられるように，光化学大気污染によっ て生成されたオキシダントやその他の物質が大都市圈 より数百 $\mathrm{km}$ る離れた田園地域にまで輸送される長 距離輸送の問題が生じている。以上の長距離輸送に特 いては, 従来の拡散の問題だけでなく, 污染物の地表 への沈着や， rainout， washout とよる除去を考慮 しなければならない。

粒子状物質の除去機構は粒子の粒径, 形，電荷など の物理的性質によって決定されるが，ガス状物質の場 合にはガスの降水粒子に対する溶解度, 吸着率, 水, 土壌乞の他の物体表面への吸着, 吸収率, さらに変換 率などの物理化学的性質によって決定される。

\footnotetext{
*工学部衛生工学科 札幌市北区北13条西 8 丁目
}

北海道大学* 大喜多敏一

除去機構の研究に挌ける重点の一つは除去速度を求 めることである。通常除去速度は

$$
d c / d t=-k c
$$

々記載される。これは污染物の除去速度は污染物濃度 の 1 次比例すると仮定していることになる。従って 式中の除去速度定数の次元は $(\mathrm{sec})^{-1}$ となる。

除去の結果污染物の大気中に怙ける平均滞留時間が 定まる。滞留時間の物差しとしてょく用いられるのは 半減期 (half life) $T$ である。これは(1)式を積分し， $C=\mathrm{C}_{0} \mathrm{e}^{-k t}$ で $C=C_{0} / 2$ の時の時間を $T$ と拉けばよ い。従って $T=\log 2 / k$ である。

\section{2. 地表面における物質の沈着}

イギリスの Windscale に特いて原子炉が事故を起 こし，それより放出された ${ }^{131} \mathrm{I}$ が風下の広域にわた って牧草を污染した事件以来, 地表面に怙ける污染物 の沈着の研究がイギリスの Harwell 原子力研究所の Chamberlain を中心精力的に行なわれている。最 近は粒子状物質以外飞 $\mathrm{SO}_{2}$, オゾン $\left(\mathrm{O}_{3}\right)$, 二酸化窒 素 $\left(\mathrm{NO}_{2}\right)$, パーオキシアセチルナイトレート(PAN) などについても沈着速度が求められている。特に $\mathrm{SO}_{2}$ についての研究が多い。また最近は単に沈着速度を求 めるだけでなく, 細かい沈着機構についても研究が行 なわれている。これらの研究の目的としては前伐べ た污染物の循環に及ぽす沈着の影響を見ると共に, 植 物に対する污染物の影響, 草食動物やその動物の肉や 乳を食用とする人体への影響を推定することもあげら 孔る。

地表面への物質の沈着量は, 単位時間内に括ける単 位地表面への物質の流束 (flux $\cdot \mathrm{cm}^{-2} \mathrm{sec}^{-1}$ ) で示され るが，流速 $=C v_{d}$ と打いた場合（ $C$ はある高さ，通 常は $1 \mathrm{~m}$ に特ける物質の濃度), $v_{d}$ を沈着速度とい う。沈着速度の逆数を沈着に対する抵抵 $r$ という。 $r$ は $r=r_{a}+r_{b}+r_{c}$ の 3 部分に分けられ, $r_{a}$ : 乱流 境界層に括将る抵抵, $r_{b}$ : 層流境界層内の分子拡散に 伴なら抵抗， $r_{c}$ : 物体表面に括ける化学反応などに伴 
なら抵抗である。

物質の沈着量の測定法は，(1)質量バランスの測定, (2)勾配（Gradient）法に二大別される。質量バラン スの測定では，例えば土壤や植物をポットなどに入れ てチェンバー中に和き，チェンバー内に被測定ガスや 粒子を導入し，その濃度の時間変化を測定する。その 場合チェンバー内にあらかじめ何も置かない場合のい わゆるブランク時の濃度をも測定し，ブランク值を差 し引く必要がある。静止空気を用いたチェンバー実験 に代って風洞を用いた実験もある。この場合には流入 流出気流中の物質量の差が沈着量になるが，同様にブ ランク值を差し引く必要がある。しかしこれらの方法 では, 気流形が大気中のものと異なるために, 先に述 ベた $r_{a}$ は求められない。

質量バランス法では放射性物質を用いることがあ り，その代表的なものとしては ${ }^{35} \mathrm{SO}_{2},{ }^{131} \mathrm{I}_{2}$ がある。 放射性物質を利用する利点として，一般には測定感度 を向上させるが，その他例えば硫黄化合物は土壌なぞ 自然界に広く分布しているので, 放射性同位体を用い ると自然界の硫黄の妨害を除くことができる。

以上の室内実験を通してガスの沈着部では流束が一 定であるという仮定が成立するようガスを導入しなけ ればならない。

質量バランスにもとづく沈着速度の計算の一例とし て Israel ${ }^{15)}$ がアルファルファ上への $\mathrm{HF}$ の沈着に用 いた式を示すと，

$$
v g=\frac{C_{A e f}}{C_{H F}} \times \frac{W}{T}
$$

$C_{A e f}:$ アルファルファ中の ふっ 素濃度, $C_{H F}$ : 大気 中のふっ素濃度, $T$ : 暴露時間, $W: 1 \mathrm{~cm}^{2}$ 当たりの アルファルファの重量となる。

地表面上に和けるガスやエーロゾルの濃度勾配を測 定し, それよりガスの流束を求める研究は, 最初水蒸 気や $\mathrm{CO}_{2}$ 流束を求めるのに用いられたが，最近では 各種微量ガスやエーロゾルの流束の測定に用いられる ようになった。流束は通常

$$
F=k_{V} \partial c / \partial z+v_{S} c
$$

で与えられる。 $\partial c / \partial z$ はガスやエーロゾルの濃度勾 配， $k_{V}$ は物質の拡散係数， $v_{S}$ は重力による落下速 度である。

熱の流束 $Q_{0}$ は

$$
Q_{0} / c_{P} \rho=-k_{H} \partial \theta / \partial z
$$

で与えられる。 $c_{P}$ : 空気の定圧比熱, $\rho$ : 空気の密度, $k_{H}$ : 熱の 拡散係数で $k_{H}=k_{V}$ である。 $\partial \theta / \partial z:$ 温度 の垂直方向の勾配である。超音波風速計を用いれば $\overline{\theta^{\prime} w^{\prime}}=Q_{0} / c_{P} \rho$ が測定できるので, 従って(2)より $k_{H}$ を求めることができ，(1)式より $F$ を求めることがで きる。

以上は熱の払散係数より求めた流束であるが，他方 風の測定すわちモーメンタムの拡散係数 $k_{M}$ が $k_{V}$ と 等しいと物いて求める方法がある。ただし安定度が中 立である場合に限られる。この場合 $k_{M}=k u_{*} z$ で与党 られる。また風速分布は

$$
u / u_{*}=1 / k \ln z / z_{0}
$$

であらわされる。 $u$ : 高さ $z$ に特ける風速である。め るいは $k_{M}=k_{V}$ より

$$
\frac{F}{\partial c / \partial z}=-\frac{t / \rho}{\partial U / \partial z} \quad F=-\frac{\tau}{\rho}\left(\frac{C_{2}-C_{1}}{U_{2}-U_{1}}\right)
$$

$\tau$ : shear stress, $\rho$ : 空気密度, $C_{1}, C_{2}, U_{1}, U_{2}$, は高さ $z_{1}, z_{2}$ に打ける物質濃度拈よび風速である。 また $\tau / \rho=u^{2} *$ であるので $(3,4)$ 式に組合せると

$$
F=\frac{k^{2}\left(U_{1}-U_{2}\right)\left(C_{2}-C_{1}\right)}{\left(\ln z_{2} / z_{1}\right)^{2}}
$$

より $F$ を求めることができる。

ガスの水面に和ける吸収による流束 $F$ は

$$
F=+\left.K_{z} \frac{\partial C}{\partial z}\right|_{z=0}=K_{G}\left(P-P_{e}\right)=K_{L}\left(C_{e}-C\right)
$$

と書くことができる。 $P$ : 大気中に拉ける物質の分 圧, $P_{e}$ : 液相中の濃度 $C$ に平衡な物質の分圧, $C_{e}$ : 大気中の分圧 $P$ と平衡状態にある液相中の物質の濃 度である。

$K_{G}, K_{L}$ はまた

$$
\frac{1}{K_{G}}=\frac{1}{k_{G}}+\frac{H}{k_{L}}, \frac{1}{K_{L}}=\frac{1}{k_{L}}+\frac{1}{H k_{G}}
$$

であらわされる。 $k_{G}, k_{L}$ はそれぞれ気相, 液相中の拡 散係数である。 $k_{L}=D_{L} / Z_{L}, k_{G}=\frac{D_{v}}{R T Z_{G}}$ であらわさ れる。 $D_{L}, D_{v}$ はそれぞれ液相，気相中の物質の分 子拡散係数である。 $R$ : 気体常数, $T$ : 絶対温度, $Z_{L}, Z_{G}$ は各々界面における液相, 気相中の境界層の 厚さである。従って流速 $F$ は $D_{L}, D_{G}, Z_{L}, Z_{G}$, $H$ (物質のヘンリ一定数) と $P, P_{e}$ または $C_{e}, C$ が分れば求めることができる。液相内で反応しないが スについては一般に $k_{L}\left\langle\left\langle k_{G}\right.\right.$ なので液相内に拈ける 抵抵で全体の抵抵が定まる場合が多い。しかし酸性が ス（ $\mathrm{SO}_{2}, \mathrm{CO}_{2}$ など）がアルカリ性液に溶解するよ らなガス分子と液分子との反応を伴なら場合にはむし ろ気相に括ける抵抗が大きくなるとを Liss ${ }^{20)}$ は Hoover $^{12)} ら$ 求めた結果より示した。

Hoover らによれば， $k_{L}$ (反応) $=\alpha k_{L}$ (非反応), 


$$
\alpha=\frac{\tau}{(\tau-1)+\left\{\left\{\tanh \left[\left(\frac{k^{*} \tau}{D_{L}}\right)^{1 / 2} \frac{D_{L}}{k_{L}(\text { 非反応 })}\right] /\left(\frac{k^{*} \tau}{D_{L}}\right)^{1 / 2} \frac{D_{L}}{k_{L}(\text { 非反応 })}\right\}\right.}
$$

である。 $\tau:$ 溶液中のガスの 全量とイオン化した 部分 の比， $k^{*}:$ ガスの水和反応速度である。

$\mathrm{Liss}^{20)}$ は測定值より $k_{G}\left(\mathrm{SO}_{2}\right)=3,000 \mathrm{cmh}^{-1}, k_{L}$ (非反応) $=10 \mathrm{cmh}^{-1}, H\left(\mathrm{SO}_{2}\right)=3.8 \times 10^{-2}, D_{L}=2 \times$ $10^{-5} \mathrm{~cm}^{2} \mathrm{~s}^{-1}, \quad k^{*}=3.4 \times 10^{6} \mathrm{~s}^{-1}$ として $\mathrm{pH}$ の異なっ た海水中への $\mathrm{SO}_{2}$ の吸収に対する(5)式中の $1 / k_{L}$ と $1 / H k_{G}$ を比較した。その結果を表 1 亿示した。表 1 によれば $\mathrm{pH} 2.8$ 以下の場合のみ気相中の 抵抗が 低 く, 2.8 以上の場合には気相抵抗の方が大きくなる。 従って通常の $\mathrm{pH} 7$ 程度の海水の場合には海水中の 抵抗は無視してよく, 水蒸気の場合の抵抗と同じであ り, その結果吸収だけを考光た場合には $\mathrm{SO}_{2}$ の大気 中の滞流時間は10日程度となる。

他方 $\mathrm{pH}$ 7-9 の海水中への $\mathrm{CO}_{2}$ の吸収の場合の $\alpha$ 1.6 3.0程度であって, この場合には液相内の抵 抗が大であり, $\mathrm{CO}_{2}$ の大気中の 滞流時間が約 7 年で あることとよい対応を示している。

以上飞示した水との反応性の非常に強い $\mathrm{SO}_{2}$ なぞ のガスを除いて，その流束は $k_{L}=C_{L} / Z_{L}$ に関係す るので $Z_{L}$ を知る必要がある。 $Z_{L}$ は風速などの各種 の要素によって変化するが, Kanwisher は流束 (即 ๖膜厚 $Z_{L}$ の逆数）は風速の 2 乗に比例することを 見出している。

膜厚 $Z_{L}$ は放射性ガス, 例壳ば ${ }^{14} \mathrm{CO}_{2},{ }^{222} R_{n}$ 等を 測定して求められる。いま ${ }^{222} R_{n}$ の場合を例にして 議論を進めよう。海水中の ${ }^{229} R_{n}$ は ${ }^{226} R_{a}$ の壞変に よって生じるが, 平衡状態ではその生成速度が海水中 の $R_{n}$ の壊変によって生じる減少括よび大気中への 流出の速度の和に等しいとして計算すればよい。大気
中への流束は

$$
D\left(C_{S}-\alpha P\right) / Z_{L}
$$

で与兄られる。 $C_{S}$ : 境界層の底で測定した $R_{n}$ 濃度, $P:$ 空気中の $R_{n}$ の分圧, $\alpha: R_{n}$ の溶解率であって $C_{S}\langle\alpha P$ である。Broecker らはこの方法を用いて $Z_{L}$ を求め平均 $46 \mu \mathrm{m}$ の值を得ている。他方核爆発 によって生じた ${ }^{14} \mathrm{CO}_{2}$ の測定より求めた $Z_{I}$ 、 は平均 $30 \mu \mathrm{m}$ である。

以上のようにして $Z_{L}$ が求まると流束 $F$ は(1)式を 用いて求めることができる。しかしこれは液相の抵抗 が気相のそれよりも大きい場合であって, 気相の抵抗 が大きい場合には第 2 節の方法によって求める。

また大気中のガスの沈着が水面に和ける吸収のみで 決定される場合には, 次式によってそのガスの大気中 の滞留時間 $\tau$ は

$$
\tau=\frac{M}{\left(P-P_{S}\right) D / Z_{L}}
$$

で与兄られる $M: 1 \mathrm{~cm}^{2}$ 上にあるガスの総量, $P$ : ガス分圧, $P_{S}$ : 水中のガス濃度と平衡した空気中の ガス圧である。

\section{乱流相関法}

もし大気中の物質濃度の変動を応答時間の小さい測 定器で測定できれば, 沈着速度 $v_{d}$ は $v_{d}=\overline{W^{\prime} C^{\prime}} / \bar{C}$ で与えられる。 $W^{\prime}$ : 乱流の垂直変動成分, $C^{\prime}:$ 濃度 の変動, $\bar{C}$ : 平均濃度である。乱流相関法を用いた研

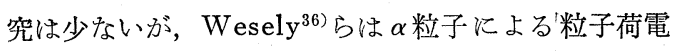
による粒子濃度の早い応答測定器を用いて粒子の流束 を求めている。

表 2 亿多くの物質の地表面への沈着速度の測定結果

表 1 海水中への $\mathrm{SO}_{2}$ の吸収に対する気相, 液相中の抵抗の比

\begin{tabular}{lccccc}
\hline $\mathrm{pH}$ & $\alpha$ & $\begin{array}{c}k_{L\left(\mathrm{SO}_{2}\right)} \\
\mathrm{cmh}^{-1}\end{array}$ & $\begin{array}{c}1 / k_{L\left(\mathrm{SO}_{2}\right)}=\gamma_{2} \\
\mathrm{hcm}^{-1} \times 10^{5}\end{array}$ & $\begin{array}{c}1 / \mathrm{H}_{g\left(\mathrm{SO}_{2}\right)=\gamma_{g}} \\
\mathrm{hcm}^{-1} \times 10^{3}\end{array}$ & $\gamma_{g} / \gamma_{l}$ \\
\hline 2 & 2.7 & 27 & 3,700 & 8.8 & 0.24 \\
2.8 & 11.7 & 117 & 855 & 8.8 & 1.03 \\
3 & 18.0 & 180 & 560 & 8.8 & 1.57 \\
4 & 169 & 1,690 & 59 & 8.8 & 14.92 \\
5 & 1,376 & 13,760 & 7.3 & 8.8 & 120.6 \\
6 & 2,884 & 28,840 & 3.5 & 8.8 & 251.4 \\
7 & 2,966 & 29,660 & 3.4 & 8.8 & 258.8 \\
8 & 2,967 & 29,670 & 3.4 & 8.8 & 258.8 \\
9 & 2,967 & 29,670 & 3.4 & 8.8 & 258.8 \\
\hline
\end{tabular}


表 2 ガ オ お び粒子 の

\begin{tabular}{|c|c|c|c|c|c|}
\hline & 研 究 者 & 年 & ガ & 対 & 方 法 \\
\hline & Thomas 5 & 1943 & $\mathrm{SO}_{2}$ & アルファルファ & 質量バランス \\
\hline & Spedding & 1969 & II & 大麦 & \\
\hline & Hill & 1971 & $\prime \prime$ & アルファルファ & 質量バランス \\
\hline & Braun 5 & 1970 & $\prime \prime$ & 都市建築物 & \\
\hline & 斉藤ら & 1971 & $\prime \prime$ & ライグラス & 勾配法 \\
\hline & Bromfield & 1972 & $\prime \prime$ & 加的 & 質量バランス \\
\hline & Garland & 1973 & 11 & 草 & ${ }^{35} \mathrm{SO}_{2}$ \\
\hline & Garland & 1973 & $\prime \prime$ & 草 & 勾配法 \\
\hline & Whelpdale 5 & 1974 & $\prime \prime$ & 水面 & \\
\hline & & & & 草 & \\
\hline ガ & & & & 雪面 & \\
\hline & Cowling & 1974 & 11 & ライグラス & 質量バランス \\
\hline & Owers $\overline{5}$ & 1974 & 11 & 草 & ${ }^{35} \mathrm{SO}_{2}$ \\
\hline & Garland 5 & 1974 & $\prime \prime$ & 短汃い草 & 勾配法 \\
\hline & Shepherd & 1974 & $\prime \prime$ & 草 & 11 \\
\hline & Payrissat & 1975 & $\prime \prime$ & ヨーロッパ土壤 & \\
\hline & Judeikis & 1976 & $\prime \prime$ & アスファルト & \\
\hline & & & & セメント & \\
\hline & & & & $L_{0}<w$ & \\
\hline & at & & & ローム土 & \\
\hline & Petit 5 & 1976 & $\prime \prime$ & 森林内 & 勾配法 \\
\hline & Garland & 1976 & 11 & 雪 & \\
\hline & Garland & 1976 & 11 & 白垔質土猿 & 勾配法 \\
\hline & Walsh 5 & 1977 & 11 & じゅうたん & \\
\hline & & & & $\begin{array}{c}\text { エマルジョソペイント } \\
\text { ビニール壁紙 }\end{array}$ & \\
\hline & Galbally & 1971 & $\mathrm{O}_{3}$ & 草 & 勾配法 \\
\hline ス & Turner 5 & 1973 & 11 & 土藵 & "I \\
\hline & Garland 5 & 1976 & $\prime \prime$ & 草 & 質量バランス \\
\hline & & & $\prime \prime$ & 土培 & \\
\hline & & & $\prime \prime$ & 海水 & \\
\hline & Hill & & "I & 樹冠 & \\
\hline & Garland 5 & 1976 & PAN & 草 & 質量バランス \\
\hline & & & II & 乾土 & \\
\hline & & & $\prime \prime$ & 湿土 & \\
\hline & Garland 5 & 1976 & $\prime \prime$ & 海水, 蒸留水 & 質量バランス \\
\hline & Hill & & $\prime \prime$ & 樹冠 & \\
\hline & Chamberlain 5 & 1966 & $\mathrm{I}_{2}$ & 草 & ${ }^{131} \mathrm{I}$ \\
\hline & Vogt 5 & 1973 & $\|$ & 草 & 質量バランス \\
\hline & Israel & 1974 & $\mathrm{HF}$ & アルファルファ,オーチャード & 11 \\
\hline & Judeikis & 1977 & $\begin{array}{c}\mathrm{H}_{2} \mathrm{~S} \\
\text { ジメチルサルファイド }\end{array}$ & 土壌 & \\
\hline & & & 粒径 ${ }^{\mu m}$ & & \\
\hline & Thom & 1972 & & & 勾配法 \\
\hline & Peirson & 1973 & & & \\
\hline 粒 & Shepherd & 1974 & $0.05-0.1$ & 草地, 水 & 勾配法 \\
\hline & Sehnel & 1975 & & 雪 & \\
\hline & Dovland 5 & 1976 & & & 勾配法 \\
\hline & Sehmel 5 & 1976 & $0.1-1.0$ & 草地 & \\
\hline 子 & Dovland & 1976 & & 雪 & \\
\hline J & Weselz 5 & 1977 & $0.05-0.1$ & & 乱流相関法 \\
\hline & Little 5 & 1977 & $0.01-0.25$ & 樹木の葉 & 質量バランス \\
\hline
\end{tabular}




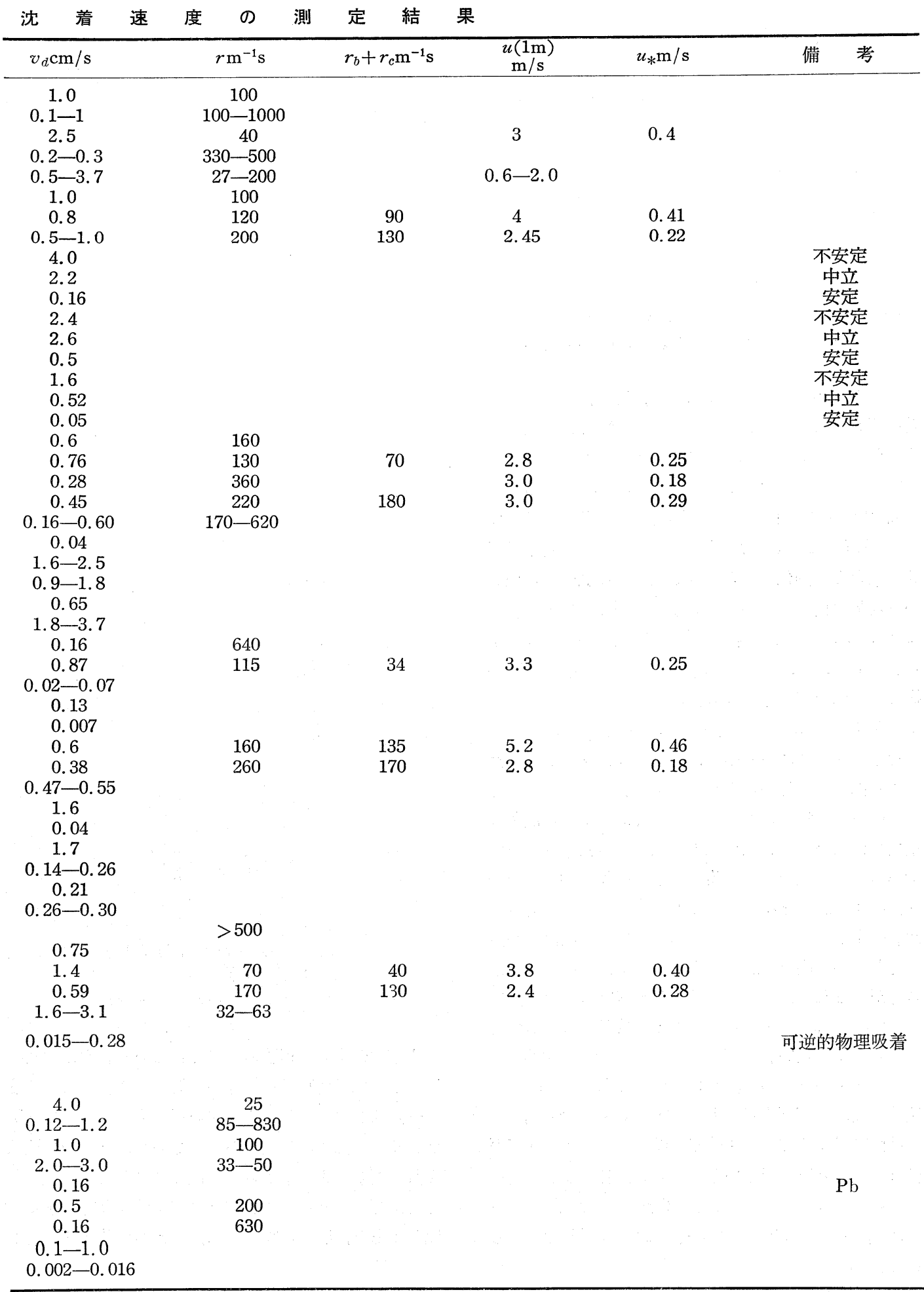




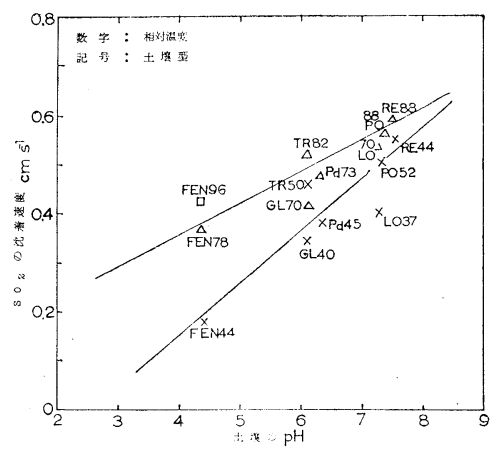

図 $1 \mathrm{SO}_{2}$ の沈着速度に対する土壃の $\mathrm{pH}$ およ び相対湿度の影響 (Payrissat らによる)

をとりまとめた。その多くは土袞, 海水, 植物への沈 着の測定結果である。土壤への 沈着は湿度と共に増 す。例えば Payrissat ${ }^{25}$ の実験結果では相対湿度が $44 \%$ より $78 \%$ に増加すると $r_{C}$ が $1 / 3$ となる（図 1)。またアルカリ土壤ではその他の土壤に比較して $r_{C}$ が $1 / 2$ となる。また $\mathrm{SO}_{2}$ の植物への沈着率が気 孔の大きさに関係するといら結果と逆に関係しないと いら結果の両者がみられる。また Whelpdale ${ }^{37)} ら に$ よれば $\mathrm{SO}_{2}$ の沈着速度は大気中の安定度に関係す る。Brimblecombe ら ${ }^{1)}$ よれば $\mathrm{NaNO}_{3},\left(\mathrm{NH}_{4}\right)_{2}$ $\mathrm{SO}_{4}, \mathrm{MnSO}_{4}$ 溶液中の塩濃度が $0.01 \mathrm{M}$ より $0.8 \mathrm{M}$ 飞変化すると $\mathrm{SO}_{2}$ の沈着速度は $1 / 3$ となる。

粒子の沈着には慣性衝突，さ党ぎり，ブラウン運動 による拡散, 電気力などが作用する。

$1 \sim 5 \mu \mathrm{m}$ の粒子の沈着については衝突による沈着は 重要ではない。植物上の細毛が粒子のさえぎりに重要 であって, 軟毛のある植物は無毛の植物の10倍も粒子 を捕集する。乱流拡散の働くところでは表面の構造は 沈着に余り影響しない。また物体の端では乱流を発生 し沈着効果を高める。小粒子に対しては乾燥したこけ の方が湿ったこけよりも有効面積が広いので沈着速度 $v_{d}$ が大さい。しかし $5 \mu \mathrm{m}$ 以上の粒子では湿面の方 が再飛散が少ない。平面の場合には $v_{d} \propto\left(S_{C}\right)^{-n}, S_{C}$ $:$ シュミット数 $=\nu / D, \nu$ : 動粘性係数, $D:$ 粒子の 拡散倸数, $n=0.67$ (滑面) $=0.5$ (粗面) である。

壁面に対する粒子の沈着速度の理論的研究 ${ }^{311}$ は壁面 付近の拡散俰数 $\varepsilon$ が求められている円管の場合につい てのみなされてきた。例えば $y^{+} \leq 5$ で $\varepsilon / \nu=\left(y^{+} /\right.$ $14.5)^{3}, 5<y^{+}<30$ で $\varepsilon / \nu=\left(y^{+} / 5\right)-0.959$ で与光ら

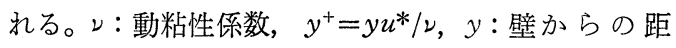
離, $u_{*}$ : 摩擦速度である。以上の払散係数を用い, 壁 面の近くである初速度でもって壁面まで粒子は自由飛

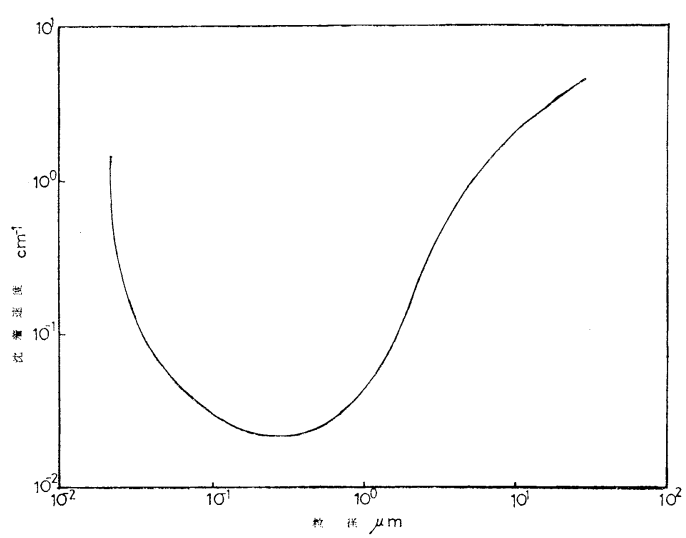

図 2 粒径と沈着速度の関係

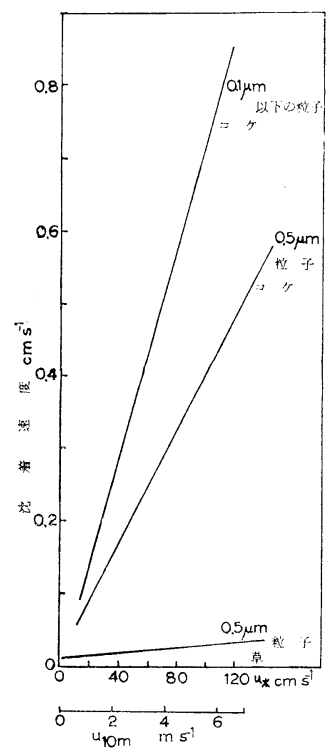

$u_{10 \mathrm{~m}}$ : 高さ $10 \mathrm{~m}$ に拈ける風速 $u_{*}$ : 摩擦速度

図 3 粒子の草, コケへの沈着速度

行すると仮定して理論がたてられている。また壁面に 沈着した粒子は再飛散しないと仮定する。実験と理論 の一致はかならずしもよくないが，その一因として壁 面近くでは粒子が乱流に追随しないために粒子の拡散 係数が運動量またはガスの拡散係数より大きくなるた めであると考兄ら机る。図 2 は粒子粒径と沈着速度の 関係であり，図 3 は粒子の草, コケへの沈着速度と風 速との関係である。

\section{3. 降水による污染物の洗浄}

降水による污染物の洗浄は, 污染物がまず雲滴中に 
捕捉せられ，次いで雲が雨や雪に捕捉される rainout 之雲底下で污染物が直接雨や雪に捕捉される washout 飞大別される。これらの作用による洗浄率 $k\left(\mathrm{sec}^{-1}\right)=D / C$ であらわされる。単位底面積の垂直 柱を考光，その中に含まれている污染物の 総量を $C$ （g）とし，その中より降水によって単位時間内に地 表に降下する物質の量を $D\left(\mathrm{~g} \cdot \mathrm{sec}^{-1}\right)$ とする。

降水による洗浄作用としてガス状物質の雲滴や雨滴 内への吸収，粒子状物質の滴への慣性衝突，ブラウン 運動による沈着, 熱沈着, 蒸気沈着, 粒子や滴が電荷 をもっているために生ずる電気力，さらに乱流による 併合によって滴に捕集される。

雨滴によるエーロゾル粒子の捕集の基本的な作用に ついては Grover ${ }^{9)}$ の最近の論文にくわしく記載され ている。作用としてはブラウン運動による拡散，熱拡 散, 蒸気拡散による粒子の雨滴への沈着, 慣性衝突が あげられる。またこれらの作用に対する雨滴や粒子の 荷電の影響がある。例えばブラウン運動を省略した場 合（即ち比載的大きな粒子の運動は）

$$
\begin{aligned}
m \frac{\overrightarrow{d v}}{d t}= & m \vec{g}_{*}-\left[6 \pi r \eta(\vec{v}-u) /\left(1+\alpha \mathrm{N}_{k n}\right)\right] \\
& +\vec{F}_{T^{\prime} h}+\vec{F}_{D f}+\vec{F}_{e}
\end{aligned}
$$

で表わされる。 $m:$ エーロゾル粒子の質量, $\vec{v}$ : 粒子 速度, $r$ : 粒子半径, $t:$ 時間, $\vec{g}_{*}=\vec{g}\left(\rho_{p}-\rho\right) / \rho_{p}, \rho_{p}$ : 粒子密度, $\rho$ : 空気密度, $\eta$ : 空気動粘性係数, $\vec{u}$ : 空気速度, $1+\alpha N_{k n}$ : 粒子抵抗に対するStokesCunningham 補正, $N_{k n}=\lambda / r$ : クヌードセン数, $\lambda$ : 空気分子の平均自由行程, $\alpha=1.25+0.44 \mathrm{exp}$ ($\left.1.07 N_{k n}{ }^{-1}\right), \overrightarrow{F_{T h}}, \overrightarrow{F_{D f}}, \overrightarrow{F_{e}}$ はそれぞれエーロゾル 粒子飞働らく熱拡散, 蒸気拡散拉よび電気による力で ある。 $\vec{F}_{T h}, \vec{F}_{D f}, \vec{F}_{e}$ はそれぞれ次の式で表わされ る。

$$
\vec{F}_{T h}=-\frac{12 \pi r \eta\left(k+C t k_{p} N_{k n}\right)}{5\left(1+3 C_{m} N_{k n}\right)\left(k_{p}+2 k+2 C_{t} k N_{k n}\right) P} k_{\nabla} T
$$

$P:$ 気圧, $k, k_{p}:$ 空気佂よびエーロゾル 粒子の 熱 伝導率, $\nabla T$ : 気温の勾配, $G=2.5, C_{m}=1.0$ である。

$$
\vec{F}_{D f}=-6 \pi r \eta\left(1+\sigma_{v a} x_{a}\right) \frac{D_{v}}{x_{a}} \nabla x_{v}
$$

$x_{a}, x_{v}:$ 空気抹よび水蒸気のモル 分率, $D_{v}:$ 空気 中の水蒸気の拡散係数である。

$$
\begin{aligned}
\vec{F}_{e}= & \left\{\varepsilon r^{2} E_{0}{ }^{2}\left(F_{1} \cos ^{2} \varphi+F_{2} \sin \varphi\right)\right. \\
& +E_{0} \cos \varphi\left(F_{3} Q_{a}+F_{4} Q r\right) \\
+ & {\left.\left[\left(F_{5} Q_{a}{ }^{2}+F_{6} Q_{a} Q_{r}+F_{7} Q_{r}{ }^{2}\right) /\left(\varepsilon r^{2}\right)\right]+E_{0} Q_{r} \cos \varphi\right\} \hat{Z} } \\
& +\left\{\varepsilon r^{2} E_{0}{ }^{2} F_{S} \sin 2 \varphi+E_{0} \sin \varphi\left(F_{9} Q_{a}+F_{10} Q_{r}\right)\right.
\end{aligned}
$$

$$
\left.+E_{0} Q_{r} \sin \varphi\right\} \hat{x}
$$

$E_{0}=\left|\vec{E}_{0}\right|, \vec{E}_{0}:$ 電場, $\varphi$ : 電場々 $Z$ 軸の間の 角, $\varepsilon$ : 媒質の電媒常数, $F_{1}-F_{10}$ : 力係数, $Q_{a}, Q_{r}$ : 雨滴 およびェーロゾル上の電荷である。

雨滴による半径 $a$ の粒子捕集による Washout 係 数 $A$ は次式で与党られる。

$$
\Lambda(a)=\int_{0}^{\infty} \pi R^{2} E(a, R) F(R) d R
$$

$F(R) d R$ : 半径 $R \sim R+d R$ の雨滴の 流 束 (個数 $/ \mathrm{cm}^{2}$ $\mathrm{sec}), E:$ 雨滴による粒子の捕集効率であって，E は 次式で与えられる。

ブラウン運動による拡散：

$$
\left(0.65 \times 10^{-12}\right)\left[\frac{10^{-7}}{a^{2} R^{2}}+\frac{1}{a^{4 / 3} R}\right]
$$

さえぎり (Interception) $: 3 \frac{a}{R}$

慣性衝突 : $\left[\frac{S-1 / 12}{S+7 / 12}\right]^{3 / 2}$

$$
S \text { (ストークス係数 })=\frac{2}{9} \frac{a^{2} \rho_{p}}{R \rho_{a}} \frac{V t}{\nu}
$$

$\rho_{p}, \rho_{a}:$ 粒子と空気の 密度, $V_{t}:$ 粒子の 重力落下速 度, $\nu$ : 空気の動粘性係数である。以上の 捕集効率を 図示したものが図 4 である。またいら゙れる対数正規分 布をした雨滴による粒子の Washout 係数を求めたも のが図 5 である。氷晶による粒子の捕集効率を図 6 , 7 亿示した。

Knutson ら ${ }^{19)}$ は雪片や氷晶による粒子の捕集效率

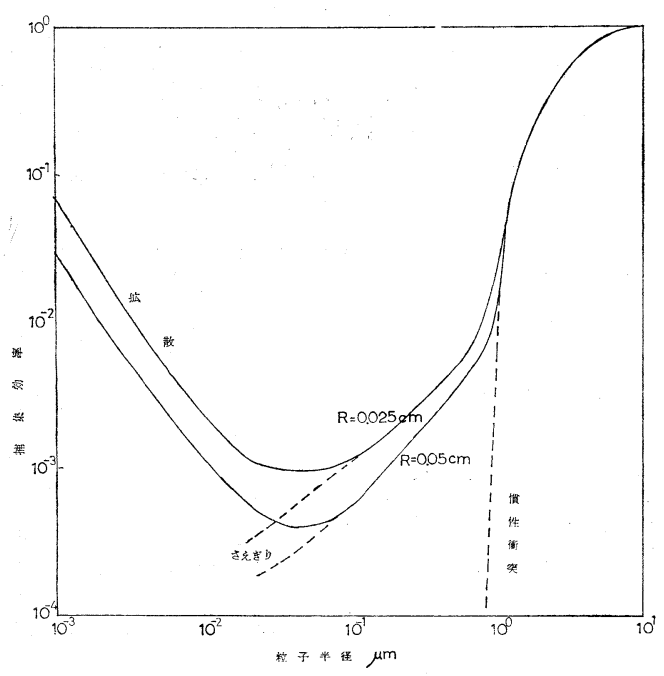

$\mathrm{R}:$ 雨滴半径

図 4 雨滴による粒子の捕集効率 


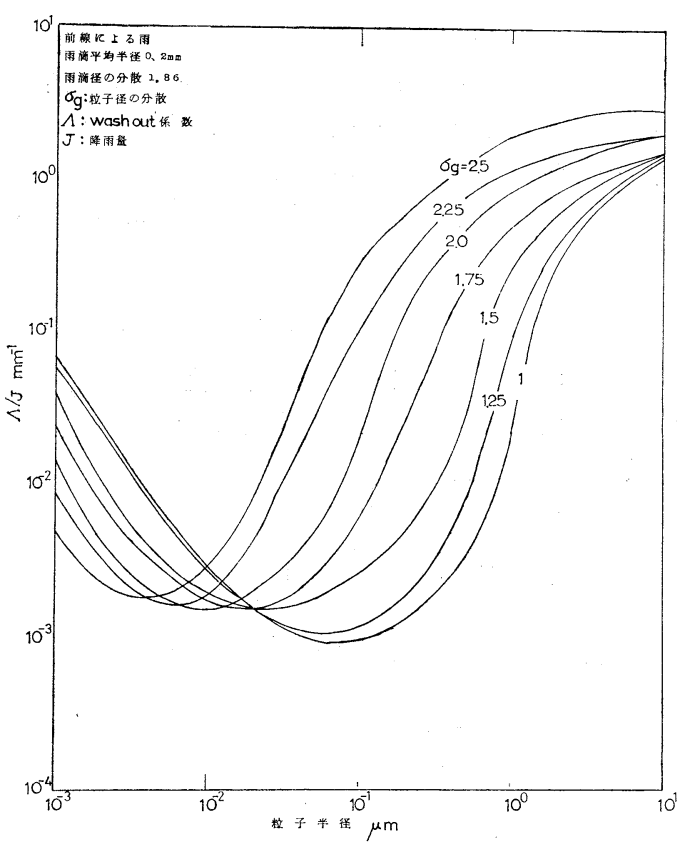

図 5 雨による粒子の washout 係数 (Dana \& Hales による)

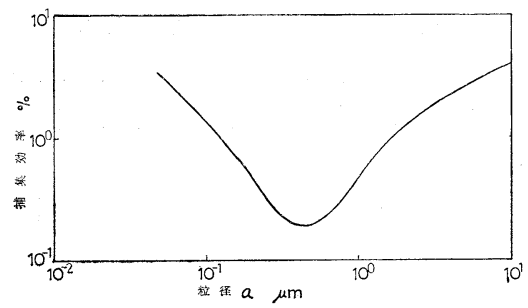
$E=\frac{4 N_{C}}{\pi D^{2} C H}, \quad \begin{gathered}N_{C}: \text { 水晶で捕集された粒子数, } \\ D: \text { 氷晶の直径, } C: \text { 大気中の粒 } \\ \text { 子濃度, } H: \text { 粒子雲の厚さ }\end{gathered}$

図 6 直径 $3 \mathrm{~mm}$ の水晶による捕集効率 $E$

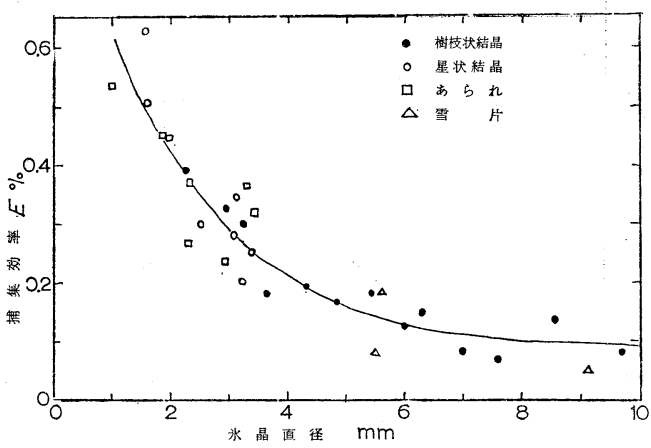

図 $70.563 \mu \mathrm{m}$ のラテックス粒子の水晶による 捕集効率
$E$ を測定し $\log _{10} E=2.477 \times 1.366 \log _{10} I$ の結果を得

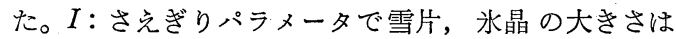
$1 \sim 10 \mathrm{~mm}$ ，粒子径は $0.25 \sim 3.5 \mu \mathrm{m}$ である。水晶の 形や静電力は影響が葟とんどなかった。

Washout, rainout 係数を求めるには上に示した 理論計算や室内に和ける測定以外に野外でトレーサ物 質，例觉ば色素，螢光物質，放射化分析の可能な金属 粒子を放出し，それらの降水による捕集を調查する方 法が試みられている。Dana ${ }^{4)}$ は水溶性色素粒子によ る調査の結果，大きい粒子については慣性捕集の理論 計算值と一致するが，半径 $0.5 \mu \mathrm{m}$ の粒子については 捕集率の測定值は理論值の10倍であって，この差を説 明するには電気的効果を考慮しなければならないとし ている。 rainout 係数を求めることはより困難なこと であるが，種々の試みがなされている。宇宙線と大気 中のアルゴンが反応して生じる ${ }^{38} \mathrm{Cl}$ (半減期37分), ${ }^{39} \mathrm{Cl}$ (55分)， ${ }^{24} \mathrm{Na}$ (15時間) の測定よりPerkins ら ${ }^{26)}$ は rainout 係数 $A=D / E_{a}$ を求めている。 $E_{a}$ : 雲 底より雲頂までの高さの底面積 $1 \mathrm{~m}^{2}$ の気柱中の ${ }^{38} \mathrm{Cl}$ の平衡量, $D$ : 地上に和ける ${ }^{38} \mathrm{Cl}$ の沈着量 $\left(\mathrm{m}^{-2} \mathrm{~s}^{-1}\right)$ である。 $A$ は $10^{-4} \sim 5 \times 10^{-3} \mathrm{~s}^{-1}$ であった。彼等はま た最初の凝結による雲粒の生成過程でほとんどの ${ }^{38} \mathrm{Cl}$ が雲粒中に入り，その後ではほとんど捕集されないこ と, 特に弱雨や中程度の雨ではその傾向が強いことを 見出している。雲中では雨滴は一部蒸発し, 併合, 凝 結を操り返す。また強雨中では蒸気沈着するというよ らな複雑な過程が含まれている。

表 3 には各研究者によって求められた粒子小よびガ スの Washout 係数である。

\section{4. 地域における降水による沈着の調査}

人工, 天然発生源より放出された物質が各種の機構 により発生源の周辺に降水により沈着する模様につい て地域的な調査がなされている。その方法としては降 水サンプラーを数十ないし数百個，小は 数十 $\mathrm{km}^{2}$ の 地域より大は大陸全体にわたって配置し，その中に捕 集された降水の量, 降水の $\mathrm{SO}_{4}{ }^{2-}, \mathrm{H}^{+}$らの成分濃 度,アルカリ度などを調査する。

調査結果をいくつかあげると, Högström ${ }^{11)}$ はスウ ェーデンのウプサラより $60 \mathrm{~km}$ 以内に 100 調査点をる らけ，ウプサラで発生した $\mathrm{SO}_{x}$ の中 $30 \%$ までが雨 や雪によって $60 \mathrm{~km}$ 以内に沈着し, その中 $98 \%$ が $\mathrm{SO}_{4}{ }^{2-}$ であり, $2 \%$ が $\mathrm{SO}_{2}$ の形であった。しかし 発生源では $\mathrm{SO}_{4}{ }^{2-} 2 \%, \mathrm{SO}_{2} 98 \%$ であり, $\mathrm{SO}_{2}$ よ り $\mathrm{SO}_{4}{ }^{2-}$ への変換がかなり早いことを推測させる。 また発生源からの距離と沈着量の間の関係より洗滌機 
表 3 (a) 粒子の washout 係数

\begin{tabular}{lcl}
\hline \multicolumn{1}{c}{ 研 究 者 } & \multicolumn{1}{c}{$\lambda\left(\mathrm{S}^{-1}\right)$} & \multicolumn{1}{c}{ 備 } \\
\hline Chamberlain (1955) & $3 \times 10^{-5}$ & 考 \\
Engleman (1965) & $16 \times 10^{\sim 5} \mathrm{~J}^{0.8}$ & 論計算 $1 \mathrm{mmh}^{-1}$ \\
Makhon'ko (1967) & $8 \times 10^{-5}$ & 野外調查 $\mathrm{Jmmh}^{-1}$ 粒径 $=5 \mu \mathrm{m}$ \\
Slinn and Hales & $0.01 \times 10^{-5}$ & 野外調査 \\
& $0.1 \times 10^{-5}$ & 粒径 $\simeq 0.1 \mu \mathrm{m}$ \\
& $3 \times 10^{-5}$ & 粒径 $\simeq 0.5 \mu \mathrm{m}$ \\
& & 粒径 $\simeq 1 \mu \mathrm{m}$ \\
Ranciteli 5 (1970) & & 理論計算 $10 \mathrm{mmh}^{-1}$ \\
Esmen (1972) & & 雨滴径 $1 \mathrm{~mm}$ \\
ACS-ESC (1974) & $0.5 \times 3 \times 10^{-4}$ & \\
Rohde and Grandell (1972) & $0.4 \times 10^{-5}$ & 野外調查 \\
\hline
\end{tabular}

表 3 (b) ガスの washout 係数

\begin{tabular}{lcl}
\hline \multicolumn{1}{c}{ 研 究 者 } & \multicolumn{1}{c}{$\lambda\left(\mathrm{S}^{-1}\right)$} & \multicolumn{1}{c}{ 備 } \\
\hline Chamberlain (1955) & $10 \times 10^{-5}$ & 考 \\
Makhon'ko & $6 \times 10^{-5}$ & 理論計算 \\
Beilke (1970) & $17 \times 10^{-5} \mathrm{~J}^{0.6}$ & $\mathrm{SO}_{2}$ 野外調査 \\
& & $\mathrm{SO}_{2}$ 室内実験 $\mathrm{Jmmh}^{-1}$ \\
& $2 \times 10^{-5}$ & $\lambda \mathrm{NO}_{2}=1 / 4 \mathrm{SO}_{2}$ \\
Hales et al. (1970) & 小規模野外実験 \\
& 大規模野外実験, $\lambda$ の值が低いの \\
& & は水滴からの $\mathrm{SO}_{2}$ の脱着による \\
大喜多 (1972) & $\mathrm{SO}_{2}$ 理論計算 $\mathrm{Jmmh}^{-1}, \mathrm{C}_{\mathrm{SO}_{2} \mathrm{ppm}}$ \\
\hline
\end{tabular}

構にはは二つあって, 発生源近くの沈着は発生源より 直接放出された $\mathrm{SO}_{2}, \mathrm{SO}_{4}{ }^{2-}$ の Washoutによるもの であり, 発生源より離れた地点での沈着は $\mathrm{SO}_{2}$ が粒 子上で $\mathrm{H}_{2} \mathrm{SO}_{4}$ 亿酸化され，それが降水注捕集される ためである。その場合アルミニウムや鉄の醋イオンが 酸化触媒となっているのであうう。Hutcheson ら ${ }^{14)}$ のアラバマ州とペンシルベニア州に括ける石炭だき火 力発電所からの $\mathrm{S}$ の降下量の調査の比較より, アラ バマでは $\mathrm{SO}_{2}$ のバックグランド濃度が低いために降 水に上る $\mathrm{SO}_{2}$ の吸収変換量が多いが，ペンシルバニ アではバックグランドの酸性が強いので, $\mathrm{SO}_{2}$ の降水

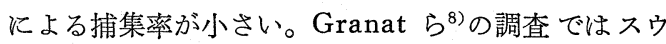
ェーデンのエーテボリの重油焚火力発電所からの $\mathrm{S} の$ 降水による降下量は, 発電所上り $15 \mathrm{~km}$ 以内（気流 の通過時間20６0分）では $1 \sim 6 \%$ ，酸性物質とし て 10〜15\% である。

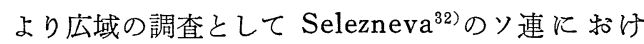
る研究がある。降水中の $\mathrm{SO}_{4}{ }^{2-}$ の平均濃度はり連で $2 \sim 12 \mathrm{mg} / l, \quad$ アメリカで $1 \sim 10 \mathrm{mg} / l$ で, 北半球の
大陸での平均 $4 \sim 6 \mathrm{mg} / l$ である。な和太平洋上の平 均濃度は海岸に和ける值より推定して $2 \sim 3 \mathrm{mg} / l$ で 西る。以上の濃度と降水量より北半球に和りる $\mathrm{S}$ の総 降下量は $2.4 \times 10^{8} \mathrm{t} \mathrm{S} /$ 年 々計算される。他方人工源 の $\mathrm{SO}_{2}$ 排出量は $8 \times 10^{7} \mathrm{t}$ であるので, 人工源からの 寄与率は $17 \%$ にすぎず，他に S の天然源があるこ とが予想される。Rodhe ${ }^{301}$ はョーロッパ北部に括け る S の沈着について研究している。まず S の天然 源が世界中で一様に分布しているものとすると，この 地域からの発生量は $1 \sim 2 \times 10^{6} \mathrm{t} \mathrm{S} /$ 年 である。他方 人工源は $10^{7} \mathrm{t} \mathrm{S} /$ 年 で，人工源の方が一桁大きい。 沈着函数 $d(r)$ を $d(r)=\frac{M}{2 \pi r_{0} r} e^{-r / r_{0}}$ で表わし, $r$ : 地域の中心加らの距離, $r_{0}=V \tau, V:$ 平均輸送速度, $\tau:$ turnover time, $M:$ 放出量である。距離 $0 \rightarrow a$ の 間の沈着量は $D(a)=\int_{0}^{a} 2 \pi r(d r) d r=M\left(1-e^{-a / r_{0}}\right)$ で表わされる。問題とする地域について $D(a)$ の実測 值との比較より $e^{-a / r_{0}}$ が定まり, 従って $r_{0}$ が決定さ れる。さらにて (大気中に放出されたものが沈着する 迄の時間）がきまる。計算より $r_{0}=2000 \sim 3500 \mathrm{~km}$, 
$\tau=2 \sim 4$ 日が求められた。

\section{5. モデル中での沈着機構の考慮}

最近污染物の長距離輸送モデルが多くの研究者によ って提出されている。その大半のものは地表面の境界 条件として(1)，(6)式を採用している。
Horst ${ }^{13)}$ はガウス型の拡散㮒の場合に沈着の機構を 加えた source depletion model (SODM) と surface depletion model (SUDM) を比較している。 ガウス型の拡散式の拡散函数 $D(x, y, z, h)$ は次式 で与えられる。

$$
D(x, y, z, h) \equiv \frac{u x(x, y, z)}{Q_{0}}=\frac{e^{-y^{2} / 2 \sigma_{y 2}}}{2 \pi \sigma_{y} \sigma_{z}}\left\{\exp \left[\frac{-(h-z)^{2}}{2 \sigma_{z}{ }^{2}}\right]+\exp \left[\frac{-(h+z)^{2}}{2 \sigma_{z}{ }^{2}}\right]\right\}
$$

$x, y, z$ は発生源を原点とした坐標, $h$ : 㖶突の高さ, $u$ : 平均風速, $Q_{0}$ : 発生源の強さ, $x(x, y, z):$ 污染物 濃度, $\sigma_{y}, \sigma_{z}$ : 煙の拡がりの標準偏差である。

SODM では沈着による効果を発生源の強さが下流 に行くにしたがって減少するとして表示する。すなわ b

$$
x(x, y, z)=Q(x) \frac{D}{u}(x, y, z, h)
$$

で質量保存則より

$$
x(x, y, z)=Q_{0} \frac{D}{u}(x, y, z, h)-\int_{-\infty}^{\infty} \int_{0}^{x} \frac{u_{d}}{u} x\left(\xi, \eta, z_{d}\right) D(x-\xi, y-\eta, z, O) d \xi d \eta
$$
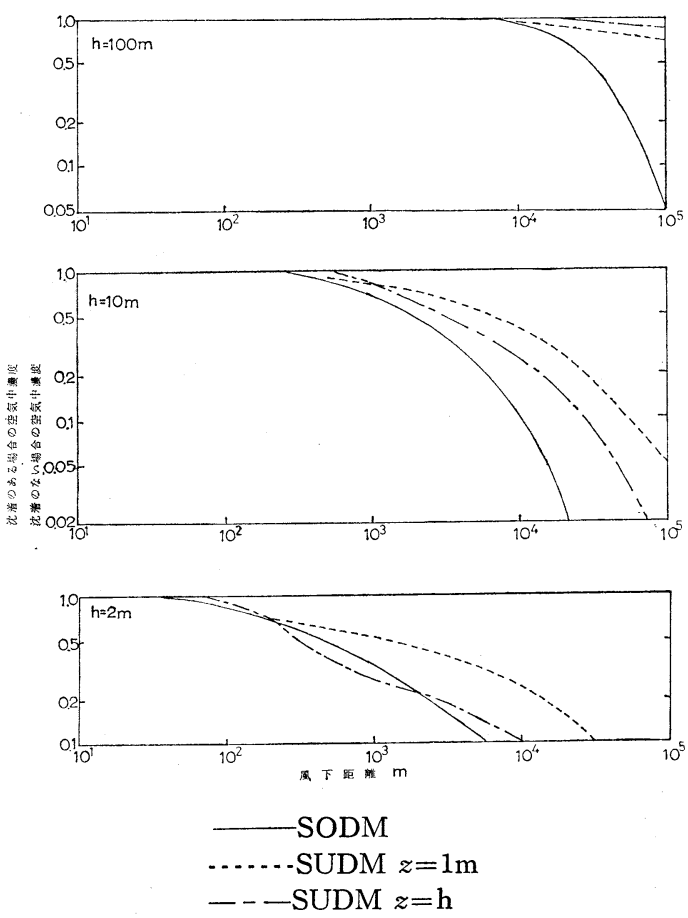

図 $8 v_{d} / \mathbf{u}=10^{-2}$ で安定時（パキスル安定度 $\mathrm{F}$ ） の SODM と SUDM の比較

で右辺の第 1 項は発生源による項, 第 2 項が沈着によ る項である。図 8 は安定気層内に新いて ${ }^{\prime} d u=10^{-2}$ の場合の沈着のない場合に比較した SODM, SUDM の場合の風下濃度である。

\section{6. 放射性元素を用いた㴆留時間の測定}

大気中のラドン $\left({ }^{222} R n\right)$ 抢よびその娘元素を測定 して，それよりエーロゾルの滞留時間を求める方法が ある。ラジウム $\left({ }^{226} R a\right)$ の $\alpha$ 崩壊によって生じた $R n$ は図 9 に示したような崩壊をし，同時に大気中の エーロゾルに付着する。各放射性元素の生成消減は

$$
d N_{2} / d t=N_{1} \lambda_{1}-N_{2}\left(\lambda_{2}+\lambda_{R}\right)
$$

であらわされる。 $N_{1}, N_{2}$ : 親元素および娘元素の原 子数, $\lambda_{1}, \lambda_{2}$ : 親元素扔よび娘元素の崩壊定数, $\lambda_{R}$ : エーロゾルの大気中からの除去速度定数である。エー

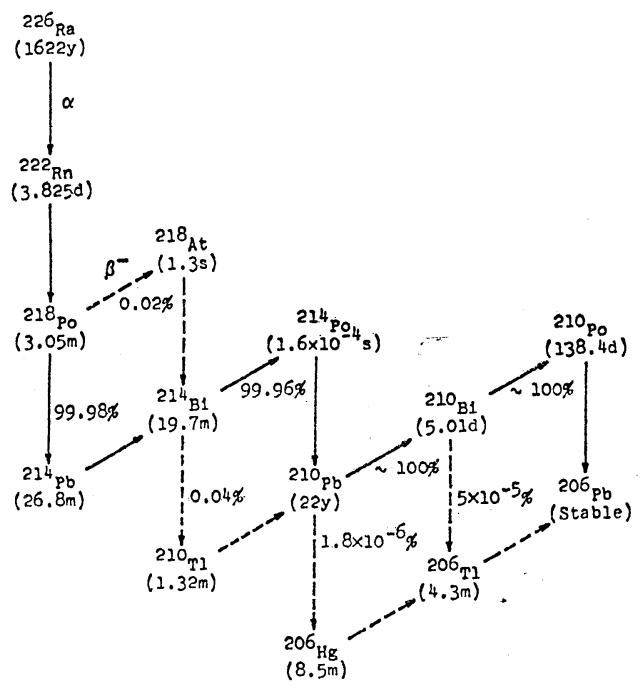

図 $9{ }^{226} \mathbf{R a}$ 崩壊 図 
表 4 各種の放射性元素を用いた対流圈中のエー ロゾルの平均帯留時間 $\left(\tau_{R}\right)$

\begin{tabular}{|c|c|}
\hline 法 & $\tau_{R}$ (日) \\
\hline 雨水中の ${ }^{7} \mathrm{Be} /{ }^{32} \mathrm{P}$ 比 & $35-40$ \\
\hline 核爆発による放射性元素の減少率 & 30 \\
\hline${ }^{90} \mathrm{Sr}$ の沈着率 & 43 \\
\hline 短寿命, 長寿命の ${ }^{222} \mathrm{R}_{n}$ 娘元素の比 & $0.8-9$ \\
\hline 雨水や空気中の ${ }^{210} \mathrm{P}_{0} /{ }^{210} \mathrm{~Pb}$ 比 & $8-65$ \\
\hline ヤコビアンドレモデル & $6-72$ \\
\hline${ }^{210} \mathrm{Bi} /{ }^{210} \mathrm{~Pb}$ 比 降水 & 7 \\
\hline 下層対流圈 & 4 \\
\hline 雨水中の ${ }^{210} \mathrm{Bi} /{ }^{210} \mathrm{~Pb}$ 比 & 6 \\
\hline
\end{tabular}

ロゾルの平均滞留時間は $\tau_{R}=1 / \lambda_{R}$ で与えられる。

図より $\tau_{R}(R n / P b)=A_{p b} \tau_{p b} / A_{R n}, \tau_{R}(B i / P b)=$ $A_{B i} \tau_{B i} /\left(A P_{b}-A_{B i}\right) \tau_{R}\left(P_{0} / P_{b}\right)=\left[-b+\left(b^{2}-4 a c\right)\right.$ $\left.{ }^{1 / 2}\right] / 2 a, a=A P_{b}-A P_{0}, \quad b=-A P_{0}\left(\tau_{B i}+\tau P_{0}\right) C=$ $-A P_{0}\left(\tau_{B i}\right)\left(\tau P_{0}\right), A=N \lambda, \tau=1 / \lambda$ で $\tau_{R}$ が計算で きる。

また Jacobi と Andre のモデルでは大気中の $R n$ 特よび娘元素の高度分布より

$$
\left\{\begin{array}{l}
\frac{d}{d z}\left(K \frac{d N_{1}}{d z}\right)-N_{1} \lambda_{1}=0 \\
\frac{d}{d z}\left(K \frac{d N i}{d z}\right)+N_{i-1} \lambda_{i-1}-N_{i}\left(\lambda_{i}+\lambda_{R}\right)=0
\end{array}\right.
$$

$K$ : 乱流拡散係数, $z$ : 高さ, 1 は $R n$ を示し, $i$ は 娘元素を示している。 $K$ としては適当な值を仮定す る。以上の各方法によって求めた $\tau_{R}$ は必ずしも一 致しないが, Moore らによると対流圈の下層では 4 日以下で対流圏上層では増加するが増加率は 3 倍以下 である。表 4 にはその他の放射性元素を用いて求めた 光を示した。

7. 各物質の沈着機構, 平均寿命, バックグランド 濃度

以下に沈着機構, 平均寿命, バックグランド濃度に ついてデータの蓄積されたものについて記載する。し かしまだデータが十分でなく以下の数字は変化する可 能性があることを指摘して执きたい。

\section{1 メタン}

メタンの年間発生量は $55-11 \times 10^{14} \mathrm{~g} /$ 年 であり, 対流圈内の平均濃度は $1.4 \mathrm{ppm}$ であってその総量は $4 \times 10^{15} \mathrm{~g}$ である。したがって平均寿命は 4 〜 年で ある。メタンの破壊は主として対流圈内で $\mathrm{CH}_{4}+$ $\mathrm{OH} \rightarrow \mathrm{CH}_{3} \cdot+\mathrm{H}_{2} \mathrm{O}$ の反応によって生ずるが，10\%は 成層圈で 破壊 される。反応サイクルは $\mathrm{CH}_{3} \cdot+\mathrm{O}_{2} \rightarrow$ $\mathrm{CH}_{3} \mathrm{O}_{2}, \mathrm{CH}_{3} \mathrm{O}_{2}+\mathrm{NO} \rightarrow \mathrm{CH}_{3} \mathrm{O}+\mathrm{NO}_{2}, \mathrm{CH}_{3} \mathrm{O}+\mathrm{O}_{2} \rightarrow$
$\mathrm{H}_{2} \mathrm{CO}+\mathrm{HO}_{2}, \quad \mathrm{H}_{2} \mathrm{CO}+\mathrm{OH} \rightarrow \mathrm{CHO}+\mathrm{H}_{2} \mathrm{O}, \quad \mathrm{H}_{2} \mathrm{CO}$ $+h \nu \rightarrow \mathrm{H}_{2}+\mathrm{CO}, \mathrm{H}_{2} \mathrm{CO}+h \nu \rightarrow \mathrm{CHO}+\mathrm{H}, \mathrm{CHO}+\mathrm{O}_{2}$ $\rightarrow \mathrm{CO}+\mathrm{HO}_{2}, \mathrm{HO}_{2}+\mathrm{NO} \rightarrow \mathrm{NO}_{2}+\mathrm{OH}$ である。

\section{$7.2 \mathrm{CO}$}

$\mathrm{CO}$ の年間発生量は $2.5 \sim 5.0 \times 10^{15} \mathrm{~g}$ であって, 対流圏内の総量は約 $2.5 \times 10^{15} \mathrm{~g}$ であるから, 平均寿 命は0.5〜1年である。CO は土壤中のバクテリアに よって消費せられ，その総量は年間 $4.5 \times 10^{14} \mathrm{~g}$ (北 半球 $3 \times 10^{14} \mathrm{~g}$, 南半球 $1.5 \times 10^{14} \mathrm{~g}$ ), 対流圈内で $\mathrm{CO}$ $+\mathrm{OH} \rightarrow \mathrm{CO}_{2}+\mathrm{H}$ の反応によって $4-10 \times 10^{14} \mathrm{~g} /$ 年 消 費される。その他成層圏へ流入するもの, 植物に吸収 されるものがある。

\section{3 硫黄化合物}

硫黄化合物の循環についてはいくつかのモデルが提

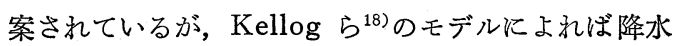
による沈着量は海上で $217\left(\times 10^{6} \mathrm{t} /\right.$ 年), 陸上で 258 , 植物などの陸上の地表面への沈着 $\mathrm{SO}_{2} 45, \mathrm{SO}_{4}{ }^{2-} 30$ で海面上に特ける $\mathrm{SO}_{2}$ 沈着量はよくはわかってい ない。対流圈内に持ける硫黄化合物の平均濃度は Robinson ら ${ }^{29)}$ によば $\mathrm{SO}_{2} 0.2 \mathrm{ppb}, \mathrm{H}_{2} \mathrm{~S} 0.2 \mathrm{ppb}$, $\mathrm{SO}_{4}{ }^{2-} 2 \mu \mathrm{g} / \mathrm{m}^{3}$ であって, Robinson らによれば対流 圈内の $\mathrm{H}_{2} \mathrm{~S}, \mathrm{SO}_{2}, \mathrm{SO}_{4}{ }^{2-}$ の平均寿命は特の沶の, $4.0 ， 6.5$ 和よび22.7日と推定されている。

\section{4 窒素化合物}

$\mathrm{NO}_{x}$ の循環に扣いて $\mathrm{NO}_{x}$ (主として $\mathrm{NO}_{2}$ ) の地 表面に和ける沈着量は $478\left(\times 10^{6} \mathrm{t} /\right.$ 年 $)$ で, $\mathrm{NO}_{3}^{-}$工 一ロゾルの dry fallout 和よび降水による沈着量は 沶の特の96和よび366である。 $\mathrm{NH}_{3}$ の地表面に和ける

表 5 含ハロゲン 炭化水素および $\mathrm{N}_{2} \mathrm{O}, \mathrm{SF}_{6}$ の バックグランド濃度 (Singh ら, 1977 に よる)

\begin{tabular}{lc}
\hline & 濃度 $\mathrm{ppt}$ \\
\hline フレオン $12\left(\mathrm{CCl}_{2} \mathrm{~F}_{2}\right)$ & 181 \\
フレオン $11\left(\mathrm{CCl}_{3} \mathrm{~F}\right)$ & 104 \\
フレオン $113\left(\mathrm{CCl}_{2} \mathrm{FCClF}_{2}\right)$ & 16.3 \\
$\mathrm{CCl}_{4}$ & 114 \\
$\mathrm{CH}_{3} \mathrm{Cl}$ & 953 \\
$\mathrm{CHCl}_{3}$ & 23.4 \\
$\mathrm{CH}_{3} \mathrm{I}$ & 2.4 \\
$\mathrm{CH}_{3} \mathrm{CCl}_{3}$ & 84 \\
$\mathrm{CCl}_{2} \mathrm{CCl}_{2}$ & 43.1 \\
$\mathrm{CHClCCl}_{2}$ & 14.5 \\
$\mathrm{CH}_{3} \mathrm{Br}$ & - \\
$\mathrm{N}_{2} \mathrm{O}$ & $296 \times 10^{3}$ \\
$\mathrm{SF}_{6}$ & 0.16 \\
\hline
\end{tabular}


沈着量は910で, $\mathrm{NH}_{4}{ }^{+}$エーロゾルの dry fallont 拉 よび降水による沈着量は扔の扮の56㧊よび213である。 $\mathrm{NO}_{2}$ のバックグランド濃度は 1 4 ppb といわれて いたが，最近の測定法の改善の結果この濃度はさらに 低下するよらである。 $\mathrm{NH}_{3}$ のバックグランド濃度は 約 $1 \mathrm{ppb}$ である。

\section{5 含ハロゲン炭化水素}

大気中の炭化水素については対象が複雑なせいかバ ックグランド濃度や平均寿命は出されていないが, 含 八ロダン炭化水素については地球規模の調査が行なわ

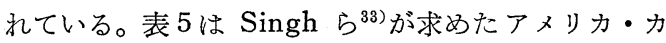
リフォルニアに和けるバックグランド濃度である。彼 等はさらにいくつかの物質について半減期を推定して いる。すなわち沃化×チル $\left(\mathrm{CH}_{3} \mathrm{I}\right) 2$ 日以内 (光解離 による), パークロロエレチン $\left(\mathrm{Cl}_{2} \mathrm{Cl}_{4}\right) 7$ 日以内。

\section{文献}

1) Brimblecombe and D. J. Spedding, Tellus, 26, 272 (1974)

2) A. C. Chamberlain, Proc. Roy. Soc., A, 290, 236 (1966)

3) W. E. Clark et al., Atm. Env., 10, 637(1976)

4) M.T.Dana, Precipitation Scavenging, AEC Symposium, Series 22, 137 (1970)

5) H. Dovland \& A.Eliassen, Atm. Env., 10, 783 (1976)

6) J. A. Garland, Atm. Env., 10, 1033 (1976)

7) J. A. Garland \& S. A. Penkett, ibid., 10, 1127 (1976)

8) L. Granat \& H. Rodhe, ibid., 7, 781 (1973)

9) S. N. Grover, H. R. Pruppacher \& A. E. Hamielec, J.Atm. Sci., 34, 1655 (1977)

10) A.C. Hill, J.APCA, 21, 341 (1971)

11) U.Högström, Atm. Env., 8, 1291 (1974)

12) T. E. Hoover \& D. C. Berkshire, J. Geophys. Res., 74, 456 (1969)

13) T.W.Horst, Atm. Env., 11, 41 (1977)

14) M. R. Hutcheson \& F. P. Hall, ibid., 8, 23 (1974)

15) G. W. Israel, ibid., 8, 1329 (1974)
16) H. S. Judeikis \& T. B. Stsewart, ibid., 10, 769 (1976)

17) H. S. Judeikis \& A. G. Wren, ibid., 11, 1221 (1977)

18) W. W. Kellogg et al., Science, 175, 587 (1972)

19) E. O. Knutson, S. K. Sood \& J. D. Stockham, ibid., 10, 395 (1976)

20) P.S. Liss, Nature, 233, 327 (1971)

21) P. Little \& R. D. Wiffen, Tellus, 11, 437 (1977)

22) T. A. McMahon et al., Atm. Env., 10, 751 (1976)

23) H. E. Moore, S. E. Poet \& E. A. Martell, J.Gepophys. Res., 78, 7065 (1973)

24） T. Okita，公衆衛生院研究報告，21，9 (1972)

25) M. Payrissat \& S. Beilke, Atm. Env., 9, 211 (1975)

26) R. W. Perkins et al., Precipitation Scavenging, AEC Symposium, Series 22, 69(1970)

27) C. Petit, M. Trinite \& P. Valentin, Atm. Env., 10, 1057 (1976)

28) L.A. Rancitelli et al., Precipitation Scavenging, AEC Symposium, Series 22, 99 (1970)

29) E. Robinson \& R.C. Robbins, Stanford Res. Inst. Project PR-6755 Supple. Rep. (1969)

30) H. Rodhe, Tellus, 24, 128 (1972)

31) G. A.Sehemel, J.Gepophys. Res., 75, 1766 (1970)

32) E. S. Selezneva, Tellus, 24, 122-127 (1972)

33) H.B.Singh, L. J. Sales \& L. A. Cavanagh, J.Air Poll. Control Assoc., 27, 332 (1977)

34) D. J.Spedding, Nature, 224, 1229 (1969)

35) M. Walsh, A Black \& A. Morgan, Atm. Env., 11, 1107 (1977)

36) M.L.Wesely et al., ibid., 11, 561 (1977)

37) D. M. Whelpdale \& R.W. Shaw, Tellus, 26, 196 (1974) 


\title{
Scavenging of Air Pollutants in the Atmosphere
}

\author{
Toshiichi OKITA \\ (Department of Health Engineering, Faculty of \\ Engineering, Hokkaido University)
}

SYNORSIS :-With the occurrence of widespread air pollution problems such as photochemical air pollution and acid precipitation, the direct deposition of the pollutants to the ground and water surface, the rainout and washout of the pollutants have to be taken into account in the long range transportation of the pollutants. In this paper the experimental and theoretical methods of estimation of the deposition to the ground and washout, and their results are reviewed. The tested materials were $\mathrm{SO}_{2}$, particulate matter, $\mathrm{NO}_{2}, \mathrm{PAN}, \mathrm{O}_{3}, \mathrm{HF}$ etc.

The inventory in the emisson and deposition of pollutants in several regions, mean life of pollutants, the effect of deposition in diffusion model of pollutants, the background concentrations, sinks and mean lifes of several important pollutants are also discussed. 